\title{
Signaling pathway for 2,3,7,8-tetrachlorodibenzo- p-dioxin-induced TNF- $\alpha$ production in differentiated THP-1 human macrophages
}

\author{
HyeonJoo Cheon ${ }^{1,4}$, Young-Seok Woo', \\ Ji Young Lee ${ }^{1,4}$, Hee Sook Kim ${ }^{1,4}$, \\ Hyun Jin $\mathrm{Kim}^{1,4}$, Sungwon $\mathrm{Cho}^{2}$, \\ Nam Hee Won ${ }^{3}$ and Jeongwon Sohn ${ }^{1,4,5}$ \\ 'Department of Biochemistry \\ ${ }^{2}$ Department of Parasitology \\ ${ }^{3}$ Department of Pathology \\ ${ }^{4}$ Korean Institute of Molecular Medicine and Nutrition \\ Korea University College of Medicine \\ Seoul 136-705, Korea \\ ${ }^{5}$ Corresponding author: Tel, 82-2-920-6192; \\ Fax, 82-2-922-6702; E-mail, biojs@korea.ac.kr
}

Accepted 19 June 2007

Abbreviations: AhR, aryl hydrocarbon receptor; NF, $\alpha$-naphthoflavone; PTK, protein tyrosine kinase; TCDD, 2,3,7,8-tetrachlorodibenzo-pdioxin

\begin{abstract}
2,3,7,8-Tetrachlorodibenzo-p-dioxin (TCDD), a prototypic halogenated aromatic hydrocarbon (HAH), is known as one of the most potent toxicants. At least a part of its toxic effects appears to be derived from its ability to induce TNF- $\alpha$ production. However, the signaling pathway of TCDD that leads to TNF- $\alpha$ expression has not been elucidated. In this study, we investigated the signaling mechanism of TCDD-induced TNF- $\alpha$ expression in PMA-differentiated THP-1 macrophages. TCDD induced both mRNA and protein expression of TNF- $\alpha$ in a dose- and time-dependent manner. $\alpha$-Naphthoflavone (NF), an aryl hydrocarbon receptor (AhR) inhibitor, prevented the TCDD-induced expression of TNF- $\alpha$ at both mRNA and protein levels. Genistein, a protein tyrosine kinase (PTK) inhibitor, and PD153035, an EGFR inhibitor, also blocked the increase of TNF- $\alpha$ expression by TCDD, indicating the role of EGFR in TCDD-induced TNF- $\alpha$ expression. On the other hand, PP2, a c-Src specific inhibitor, did not affect TCDD-induced TNF- $\alpha$ expression. EGFR phosphorylation was detected as early as 5 min after TCDD treatment. TCDD-induced EGFR activation was AhR-dependent since co-treatment with $\alpha$-NF pre-
\end{abstract}

vented it. ERK was found to be a downstream effector of EGFR activation in the signaling pathway leading to TNF- $\alpha$ production after TCDD stimulation. Activation of ERK was observed from $30 \mathrm{~min}$ after TCDD treatment. PD98059, an inhibitor of the MEK-ERK pathway, completely prevented the TNF- $\alpha$ mRNA and protein expression induced by TCDD, whereas inhibitors of JNK and p38 MAPK had no effect. PD153035, an EGFR inhibitor, as well as $\alpha$-NF significantly reduced ERK phosphorylation, suggesting that ERK activation by TCDD was mediated by both EGFR and AhR. These results indicate that TNF- $\alpha$ production by TCDD in differentiated THP-1 macrophages is AhR-dependent and involves activation of EGFR and ERK, but not c-Src, JNK, nor p38 MAPK. A signaling pathway is proposed where TCDD induces sequential activation of AhR, EGFR and ERK, leading to the increased expression of TNF- $\alpha$.

Keywords: extracellular signal-regulated MAP kinases; macrophages; receptors, aryl hydrocarbon; receptor, epidermal growth factor; tetrachlorodibenzodioxin; tumor necrosis factor- $\alpha$

\section{Introduction}

2,3,7,8-Tetrachlorodibenzo-p-dioxin (TCDD) is a prototypic halogenated aromatic hydrocarbon and considered as the most potent toxicant in this family. It causes various species- and organ-specific toxic effects, including carcinogenicity, wasting, immune suppression, reproductive toxicity, teratogenecity and death (DeVito and Birnbaum, 1995). The immune suppressive effect of TCDD includes both $B$ and $T$ cell responses. Reduced antibody responses have been shown in $B$ lymphocytes exposed to TCDD (Dooley and Holsapple, 1988; Luster et al., 1988), and in vivo studies indicate that cytotoxic and regulatory $\mathrm{T}$ cell functions may also be suppressed following TCDD exposure (Kerkvliet et al., 1990). While TCDD treatment does not alter macrophge-mediated antigen presentation, phagocytosis or tumor cell cytolysis, there is evidence suggesting that TCDD stimulates production of inflammatory mediators such as reactive oxygen species and inflammatory cyto- 
kines (Clark et al., 1991; Alsharif et al., 1994).

TNF- $\alpha$ is known as a primary mediator of an acute inflammatory response, and its over-production plays a key role in many pathologic processes (Vassalli, 1992), including TCDD associated mortality, hypersensitivity to endotoxin, an enhanced peritoneal inflammatory response, cachexia, and endometriosis (Clark et al., 1991; Moos et al., 1994; Rier et al., 2001). TCDD was reported to increase the serum TNF- $\alpha$ concentration in endotoxin-exposed mice (Clark et al., 1991), and induce TNF- $\alpha$ production in peritoneal macrophages and Raw264.7 cells after LPS stimulation (Moos et al., 1997; Pestka and Zhou, 2006).

TCDD enhanced inflammatory responses induced by intraperitoneal injection of sheep red blood cells into mice, and this hyper-inflammation was dramatically reduced by a soluble TNF- $\alpha$ receptor (Moos et al., 1994). Furthermore, anti-TNF- $\alpha$ antibodies or dexamethasone reduced TCDDmediated mortality (Taylor et al., 1992), indicating that the TNF- $\alpha$-mediated inflammatory response contributed to the TCDD toxicity. However, the mechanism or the signaling pathway by which TCDD enhances TNF- $\alpha$ production has not been clearly understood.

Most, but not all, of the biological effects of TCDD are mediated by binding to its intracellular receptor, aryl hydrocarbon receptor (AhR). AhR is a ligand-activated transcription factor belonging to a basic-helix-loop-helix (bHLH)/Per-ARNT-Sim (PAS) family (Schmidt and Bradfield, 1996). At a resting state, AhR exists in the cytoplasm as an inactive complex with a chaperone, heat shock protein 90, X-associated protein 2, and cochaperone protein, p23 (Whitelaw et al., 1993; Ma and Whitlock, 1997; Kazlauskas et al., 1999). When TCDD binds to the cytoplasmic AhR, AhR is released from the complex and translocates to the nucleus. In the nucleus, AhR associates with its dimerization partner, AhR nuclear translocator (ARNT), and interacts with xenobiotic responsive elements (XREs). XREs, also known as dioxin responsive elements, are present in genes such as phase I and II detoxification genes (Schmidt and Bradfield, 1996). In addition to its activity as a transcription factor, the ligand binding to AhR also triggers signal transduction pathways. However, this receptor-based model cannot explain all the biological effects of TCDD, and AhR-independent effects of TCDD have also been reported (Hossain et al., 1998; Ahmed et al., 2005).

Signaling pathways triggered by TCDD are diverse and largely uncharacterized. Limited information indicates that the ability of TCDD to modulate protein kinase activity plays an important role in the TCDD-induced toxicity (Bombick et al., 1985, 1988; Madhukar et al., 1988; Matsumura, 1994). TCDD immediately activates PKC and protein tyrosine kinase (PTK), such as EGFR and c-Src, in hepatocytes. It is not clear how EGFR is activated by TCDD stimulation, however, cross-talk between AhR and EGFR signaling pathways seems to play a role in hepatocarcinogenecity and the developmental toxicity induced by TCDD. c-Src is shown to be activated by TCDD in experimental animals, and the activation of $\mathrm{c}$-Src contributes to the toxicity of TCDD (Enan et al., 1998a). Park et al. (2005) also reported that TCDD activated ERK and p38 in a mouse macrophage cell line, Raw 264.7.

Despite the scattered information on the TCDDtriggered signaling mechanism and the knowledge of the molecular pathways by which the TNF- $\alpha$ expression is induced by LPS and other stimuli, the signaling mechanism of the TCDD-induced TNF- $\alpha$ expression remains unknown. In the present study, we investigated the signaling pathway involved in TCDD-induced TNF- $\alpha$ production in differentiated human THP-1 macrophages. Our data indicate that TNF- $\alpha$ production induced by TCDD results from AhR-dependent activation of EGFR and ERK, but c-Src, JNK or p38 MAPK is not involved.

\section{Materials and Methods}

\section{Chemicals}

LPS, PMA and actinomycin D were purchased from Sigma (St. Louis, MO). TCDD was purchased from Cerilliant Co. (Round Rock, TX).

\section{Cell culture and differentiation}

THP-1, a human promonocytic leukemia cell line and the Raw 264.7 mouse macrophage cell line were obtained from the American Type Culture Collection (Massas, VA) and the Korea Cell Line Bank (Seoul, Korea), respectively. Cells were maintained in RPMI-1640 (Cambrex Bio Science, Walkersville, MD) supplemented with $10 \%$ FBS, and antibiotics $(100 \mu \mathrm{g} / \mathrm{ml}$ streptomycin, $100 \mathrm{U} / \mathrm{ml}$ penicillin $\mathrm{G}$, and $0.25 \mu \mathrm{g} / \mathrm{ml}$ amphotericin B). Culture medium was tested for endotoxin contamination by Limulus Ameboecyte Lysate gel clot end point assay (Endosafe $^{\mathrm{TM}}$, Charles River laboratories, Charleston, SC), and negative for the endotoxin. The calculated value of $0.25 \mathrm{EU} / \mathrm{ml}$ was considered to be the threshold for endotoxin positivity. THP-1 cells were differentiated into macrophages by culturing with 150 nM PMA for 2 days. 


\section{Bioassay of TNF- $\alpha$}

The TNF- $\alpha$ protein concentration was calculated using a TNF- $\alpha$-sensitive mouse fibroblast cell line, L929. Briefly, L929 cells were plated at a density of $7.5 \times 10^{3} \mathrm{cells} / 150 \mu \mathrm{l} /$ well on a 96 -well plate and incubated overnight in the RPMI-1640 medium supplemented with $10 \%$ FBS and antibiotics. On the next day, the medium was discarded, and $50 \mu \mathrm{l}$ of new medium containing $2 \mu \mathrm{g} / \mathrm{ml}$ actinomycine D and $50 \mu \mathrm{l}$ of the THP-1 culture supernatant were added. A standard curve was obtained using the recombinant TNF- $\alpha$ in a range of $0.25-500 \mathrm{pg} / \mathrm{ml}$ concentrations. The culture medium was discarded after incubation for $18 \mathrm{~h}$ at $37^{\circ} \mathrm{C}$, and $50 \mu \mathrm{l}$ of $0.05 \%$ crystal violet in $20 \%$ ethanol was added. After incubation for $10 \mathrm{~min}$ at room temperature, the wells were thoroughly rinsed with tap water, and dried. Absorbance at $595 \mathrm{~nm}$ was measured with a microplate reader (Model 550, Bio-Rad, Hercules, CA) after adding $100 \mu \mathrm{l}$ of $100 \%$ methanol to each well.

\section{SYBR green real time PCR}

For quantitative analysis of mRNA expression, the total RNA was extracted, and cDNA was synthesized by reverse transcription with Moloney murine leukemia virus (MMLV) reverse transcriptase and an oligo (dT) primer. Real time PCR was performed in a SYBR Green PCR Master Mix (Applied Biosystems, Foster City, CA) containing SYBR Green 1 Dye, AmpliTaq Gold ${ }^{R}$ DNA Polymerase, dNTPs with dUTP, and optimized buffer components. Initial denaturation at $95^{\circ} \mathrm{C}$ for $10 \mathrm{~min}$ and 40 cycles of $95^{\circ} \mathrm{C}$ for $15 \mathrm{~s}$ and $60^{\circ} \mathrm{C}$ for $1 \mathrm{~min}$ were carried out using the GeneAmp 7000 Sequence Detection System (Applied Biosystems). The sequences of primers were as follow; TNF$\alpha, 5^{\prime}$-GCCAGAGGGCTGATTAGAGA-3' and 5'-TCTTCTGCCTGCTGCACTT-3'; IL-1 $\beta$, 5'-GGACAAGCTGAGGAAGATGC-3' and 5'-TCGTTATCCCATGTGTCGAA-3'; IL-8, 5'-CTGCGCCAACACAGAAATTA-3' and 5'-CTCTGCACCCAGTTTTCCTT-3'; GAPDH, 5'-AAGGTGAAGGTCGGAGTCAACG-3' and 5'-CCTTCTCCATGGTGGTGAAGAC-3'. The amount of mRNA of the target gene was normalized to that of GAPDH using the $\triangle \mathrm{Ct}$ method, as described in the manufacturer's protocol.

\section{Western blot analysis}

Cells were lysed in $1 \times$ sample loading buffer $(31.25$ $\mathrm{mM}$ Tris- $\mathrm{HCl}, \mathrm{pH} 6.8,10 \%$ glycerol, $1 \%$ SDS, $2.5 \%$ $\beta$-mercaptoethanol) and boiled for $10 \mathrm{~min}$. Protein concentrations of the lysates were measured using Coomassie Plus protein assay reagent (Pierce,
Rockford, IL). Cell lysates were subjected to SDSPAGE, and transferred onto a nitrocellulose membrane. The membrane was blocked in $5 \%$ skim milk in Tris-buffered saline with $0.1 \%$ Tween 20 (TBS-T) for $1 \mathrm{~h}$, and incubated sequentially with a primary antibody for $1.5 \mathrm{~h}$, and a HRP-conjugated secondary antibody for $1 \mathrm{~h}$. The protein band of interest was detected using the Western Blot Luminol Reagent (Santa Cruz biotechnology Inc. Santa Cruz, CA). The primary antibodies for phospho-ERK and ERK were purchased from Cell Signaling Technology Inc. (Danvers, MA) and Santa Cruz Technology Inc. (Santa Cruz, CA), respectively.

\section{Results}

\section{TCDD increases expression and secretion of TNF- $\alpha$ in differentiated THP-1 macrophages}

The effect of TCDD on TNF- $\alpha$ expression was investigated in differentiated human THP-1 macrophages. The human monocytic THP-1 cells were treated with PMA (150 nM) for 2 days to differentiate them into macrophages and exposed to various concentrations (12.5-100 $\mathrm{nM})$ of TCDD. After $24 \mathrm{~h}$ of TCDD treatment, the level of the secreted TNF- $\alpha$ protein in the culture supernatant was measured by L929 bioassay. The TNF- $\alpha$ production by TCDD was increased in a dosedependent manner up to $75 \mathrm{nM}$ (Figure 1A). At 75 $\mathrm{nM}$ of TCDD, the TNF- $\alpha$ level in the culture supernatant increased by 2-fold. Figure 1B shows temporal analysis of TNF- $\alpha$ mRNA expression assessed by real-time PCR. The level of TNF- $\alpha$ mRNA continuously increased up to $20 \mathrm{~h}$ after exposure to TCDD: At that time, the mRNA expression of TNF- $\alpha$ in the TCDD-treated cells was elevated by 4.1 fold compared to that in DMSOtreated control cells. These results show that TCDD induced both mRNA and protein expression of TNF- $\alpha$ in differentiated THP-1 macrophages. TCDD did not induce TNF- $\alpha$ expression in undifferentiated monocytic THP-1 cells at the same concentrations (data not shown).

TCDD also augmented the level of IL-8 mRNA expression by 2.7 fold, but did not significantly affect the IL-1 $\beta$ mRNA expression (Figure 1C). In contrast to the PMA-differentiated THP-1 human macrophages, Raw 264.7 murine macrophage cells, did not increase TNF- $\alpha$ expression after stimulation with TCDD alone. In Raw 264.7 cells, TNF- $\alpha$ could be induced by co-treating LPS along with TCDD (Figure 1D). 
A

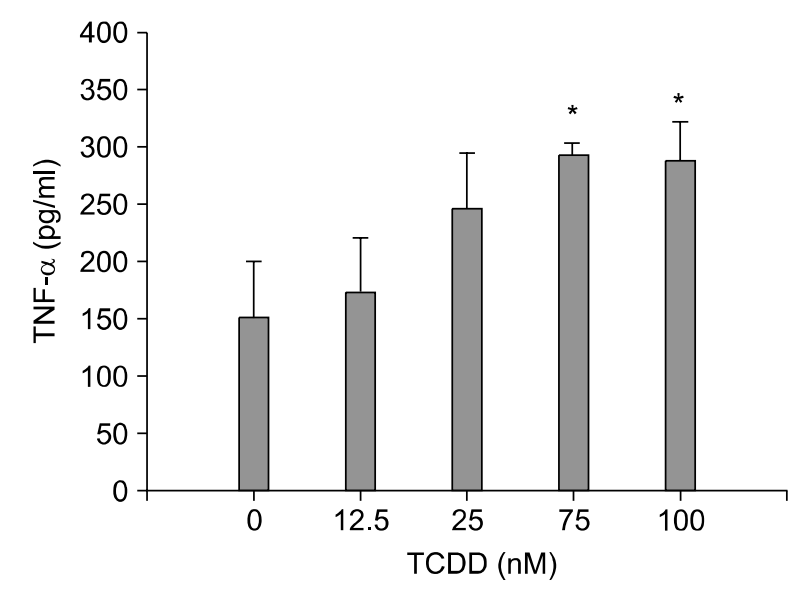

C

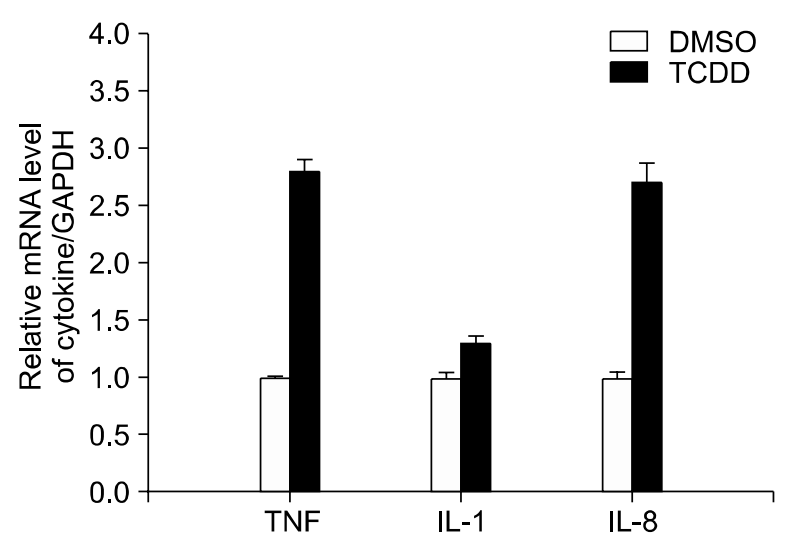

B

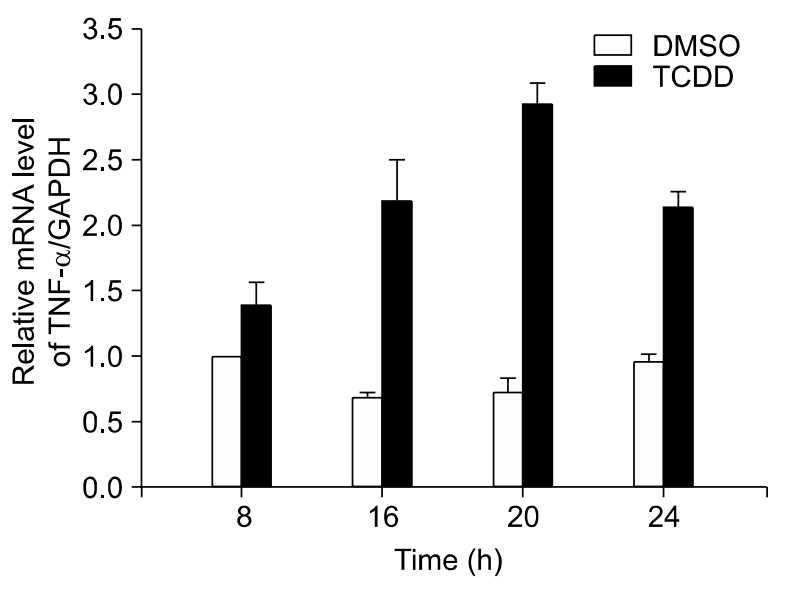

D

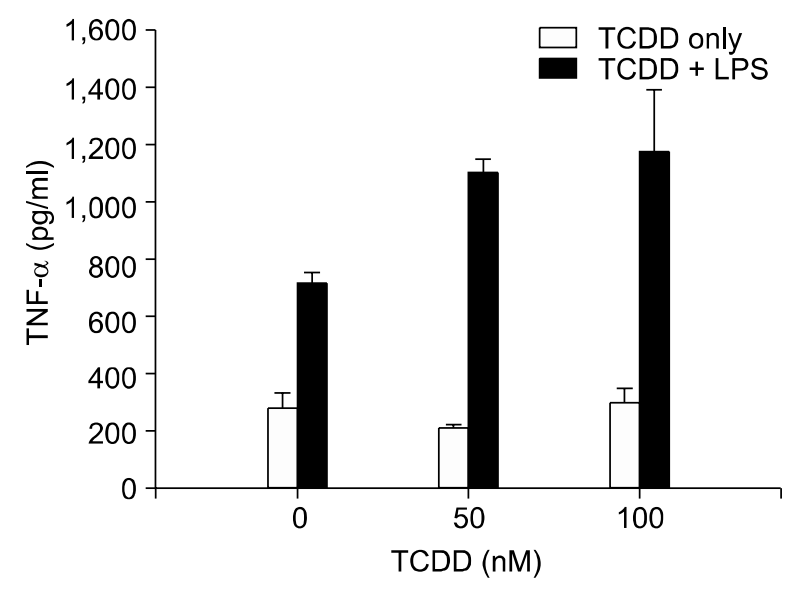

Figure 1. TCDD increases mRNA and protein expression of TNF- $\alpha$ in PMA-differentiated THP-1 cells. (A) THP-1 cells were differentiated into macrophages by culturing them with $150 \mathrm{nM}$ PMA for 2 days. Various concentrations of TCDD (12.5-100 nM) were added to THP-1 macrophages for $24 \mathrm{~h}$, and TNF- $\alpha$ concentration in the culture supernatant was measured by L929 bioassay as described in 'Materials and Methods'. Experiments were carried out in triplicate. Error bars represent standard deviation. ${ }^{*} P<0.05$ compared with the DMSO-treated control. The data shown are the representative of three independent experiments with similar results. (B) Time course analysis of TNF- $\alpha$ mRNA induction by TCDD in THP-1 macrophages. TCDD (75 nM) or DMSO was added to PMA-differentiated THP-1 cells for 8, 16, 20, and $24 \mathrm{~h}$. Total RNA was extracted, and the level of TNF- $\alpha$ mRNA was assessed by real time PCR using SYBR green. Bars represent relative mRNA expression of TNF- $\alpha$ normalized to that of GAPDH. (C) Effect of TCDD on IL-8 and IL-1 $\beta$ mRNA expression in THP-1 macrophages. TCDD $(75 \mathrm{nM})$ or DMSO was added to PMA-differentiated THP-1 cells for $20 \mathrm{~h}$. Real time PCR was performed with primer pairs specific for human IL-1 $\beta$ and IL-8. Bars represent relative mRNA expression of IL-1 $\beta$ and IL-8 normalized to that of GAPDH. (D) TCDD ( 50 and $100 \mathrm{nM}$ ) was added to Raw 264.7 murine macrophage cells for $24 \mathrm{~h}$ in the presence or absence of LPS (1 ng/ml). TNF- $\alpha$ concentration in the culture supernatant was measured by L929 bioassay. Experiments were carried out in triplicate. Error bars represent standard deviation. The data shown are the representative of three independent experiments with similar results.

\section{AhR mediates up-regulation of TNF- $\alpha$ expression by TCDD}

As a first step to elucidate the signaling pathway through which TCDD induced TNF- $\alpha$ expression, we investigated whether the increased TNF- $\alpha$ expression by TCDD was an AhR-dependent effect. Although AhR is a receptor for TCDD, AhR-independent effects of TCDD have also been reported (Hossain et al., 1998; Ahmed et al., 2005). Differentiated THP-1 macrophages were treated with $\alpha$-naphthoflavone $(\alpha-N F)$, an AhR antagonist, together with TCDD. As shown in Figure 2, $\alpha-\mathrm{NF}$ prevented up-regulation of the TNF- $\alpha$ expression induced by TCDD in a dose-dependent manner. The TCDD-induced TNF- $\alpha$ expression was completely inhibited by $1 \mu \mathrm{M} \alpha-\mathrm{NF}$ at both mRNA and protein levels. These results suggest that $A h R$ mediates the TCDD-induced TNF- $\alpha$ expression in differentiated THP-1 macrophages. 
A

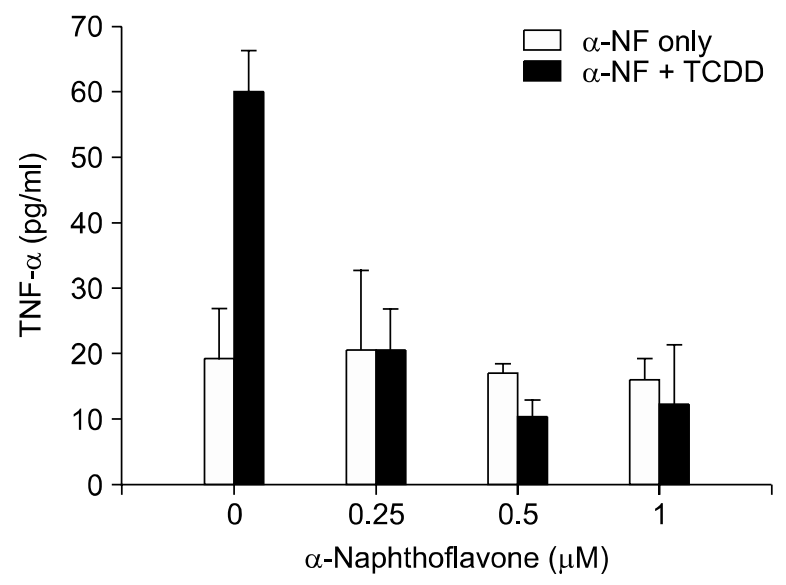

B

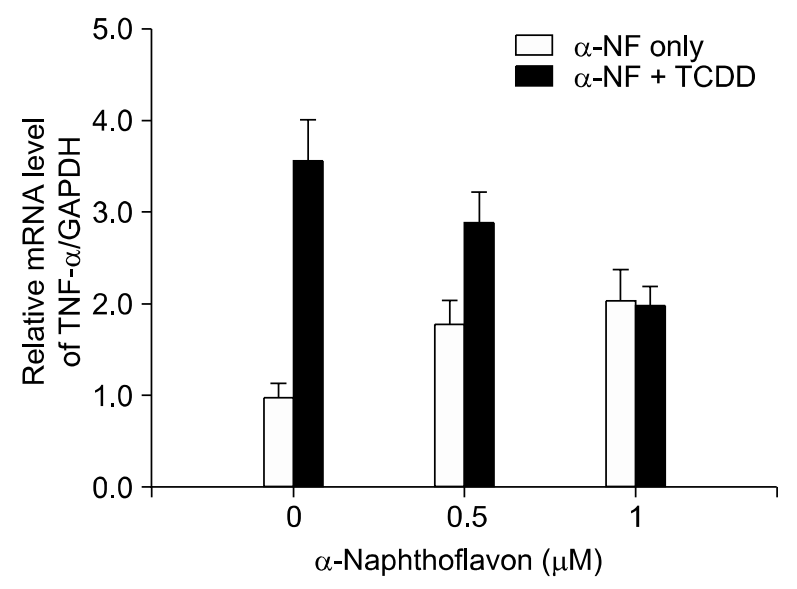

Figure 2. AhR mediates TCDD-induced up-regulation of TNF- $\alpha$ expression in THP-1 macrophages. PMA-differentiated THP-1 cells were co-treated with $75 \mathrm{nM}$ TCDD and $1 \mu \mathrm{M} \alpha-\mathrm{NF}$, an AhR antagonist. (A) After $24 \mathrm{~h}$, the TNF- $\alpha$ concentration in culture supernatant was measured by L929 bioassay. Experiments were performed in triplicate. Error bars represent standard deviation. (B) After $24 \mathrm{~h}$, the expression level of TNF- $\alpha$ mRNA was assessed by real time PCR. Bars represent relative mRNA expression of TNF- $\alpha$ normalized to that of GAPDH. The data are the representative of three independent experiments with similar results.

A

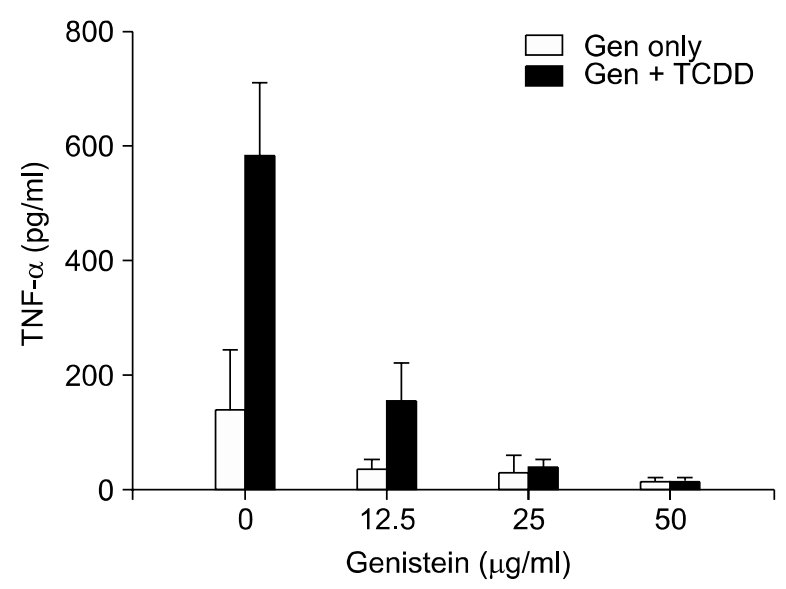

B

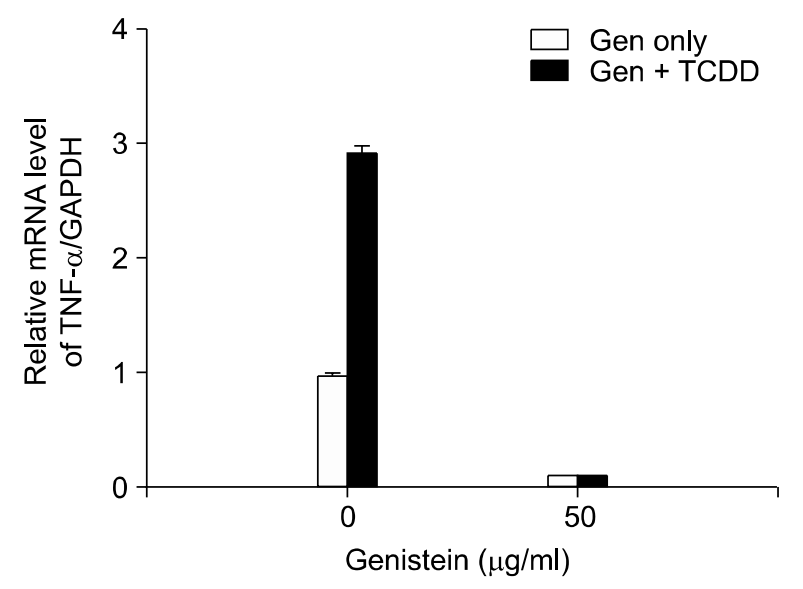

Figure 3. PTK is involved in TCDD-induced increase of TNF- $\alpha$ expression. THP-1 cells differentiated with PMA were co-treated with TCDD (75 nM) and various concentrations of genistein for $24 \mathrm{~h}$. (A) TNF- $\alpha$ concentration in culture supernatant was measured by L929 bioassay, and the experiments were carried out in triplicate. Error bars represent standard deviation. The data are the representative of three independent experiments with similar results. (B) The expression level of TNF- $\alpha$ mRNA was assessed by real time PCR. Bars represent relative mRNA expression of TNF- $\alpha$ normalized to that of GAPDH.

\section{EGFR activation is required for TCDD-induced TNF- $\alpha$ expression}

Since protein tyrosine kinases (PTKs) were implicated in the cellular responses to TCDD, the role of PTK in the up-regulation of TNF- $\alpha$ expression after TCDD treatment was investigated. Figure 3 shows that genistein, a broad spectrum PTK inhibitor, blocked the TCDD-induced TNF- $\alpha$ expression in a dose-dependent manner. Genistein at a $50 \mu \mathrm{g} / \mathrm{ml}$ concentration completely inhibited the increase of
TNF- $\alpha$ expression induced by TCDD at both mRNA and protein levels.

Therefore, we searched for the PTK that participated in the TCDD-induced signaling which led to the up-regulation of TNF- $\alpha$ expression. Roles of EGFR and c-Src, the two known TCDD-activated PTKs, were examined using chemical inhibitors. Pretreatment of the THP-1 macrophages with an EGFR inhibitor, PD153035, suppressed the TCDDinduced expression of TNF- $\alpha$ mRNA and protein 
(Figure 4A and B). The inhibition of TCDD-induced TNF- $\alpha$ expression by PD153035 was dose-dependant, and at $50 \mathrm{nM}$, the inhibition was complete. Next, EGFR activation by TCDD was investigated by an immunoblot analysis. Immunoprecipitation of EGFR followed by immunoblotting with an anti-phospho-EGFR antibody shows that EGFR is activated as early as $5 \mathrm{~min}$ after TCDD treatment (Figure 4C). The rapid kinetics suggest that EGFR activation constitutes an upstream event in the TCDD-induced signaling. On the other hand, a c-Src specific inhibitor, PP2, did not affect TCDD- induced TNF- $\alpha$ expression at concentrations up to $1 \mu \mathrm{M}$, suggesting that $\mathrm{c}-\mathrm{Src}$ activity was not required in TCDD-induced TNF- $\alpha$ expression (Figure 4D). Even higher concentrations of PP2 (up to $10 \mu \mathrm{M}$ ) failed to suppress the effect of TCDD on TNF- $\alpha$ expression (data not shown). Altogether, these results indicate that EGFR, but not c-Src, is involved in TCDD-induced TNF- $\alpha$ expression in differentiated THP-1 macrophages.
A

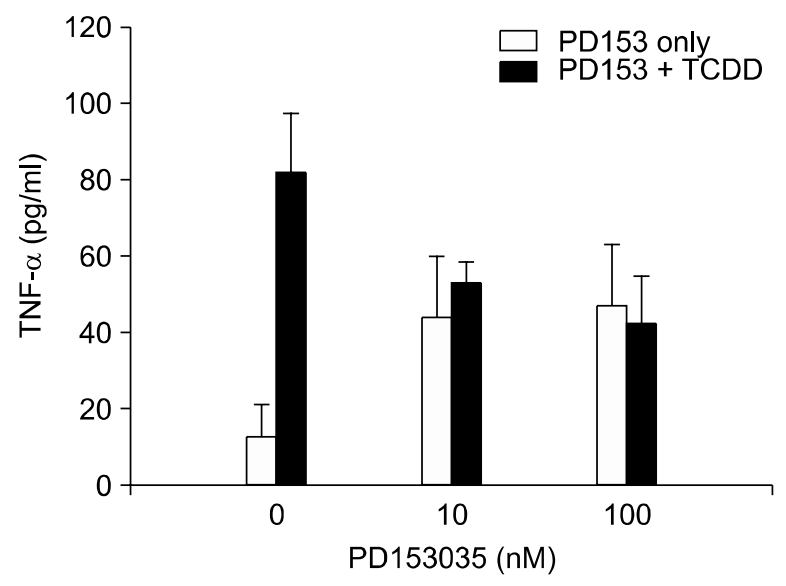

C

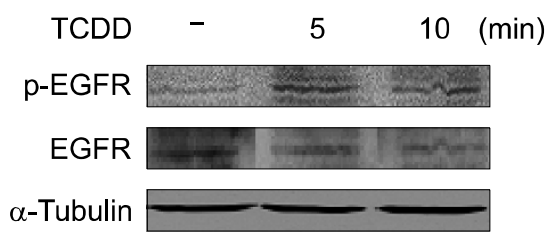

B

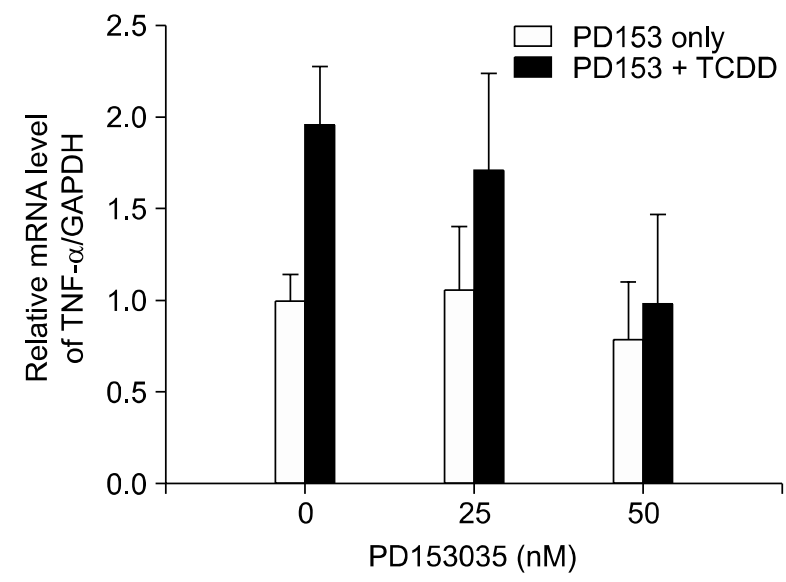

D

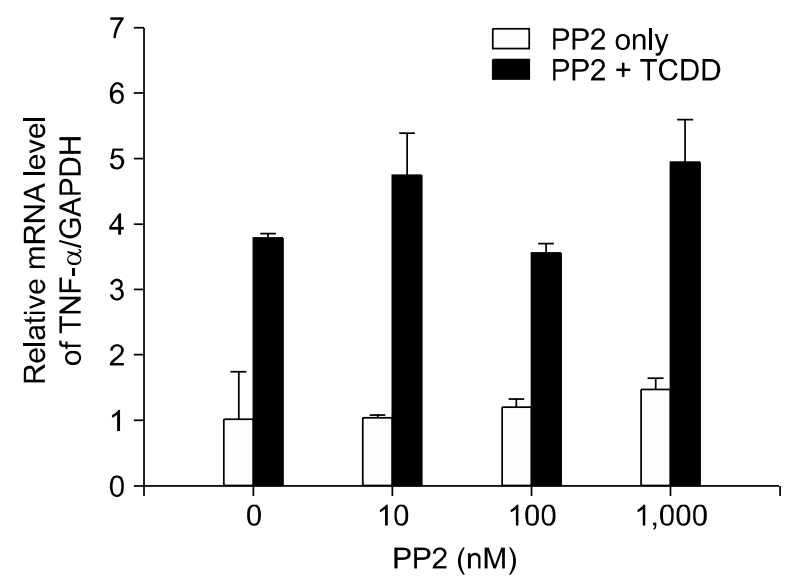

Figure 4. EGFR activity is required for TCDD-induced TNF- $\alpha$ expression. (A) PMA-differentiated THP-1 cells were co-treated with TCDD (75 nM) and various concentrations of PD153035 for $24 \mathrm{~h}$. The TNF- $\alpha$ concentration in culture supernatant was measured by L929 bioassay in triplicate. Error bars represent standard deviation. The data shown are the representative of two independent experiments with similar results. (B) PMA-differentiated THP-1 cells were co-treated with TCDD $(75 \mathrm{nM})$ and various concentrations of PD153035 for $24 \mathrm{~h}$. The expression level of TNF- $\alpha$ mRNA was assessed by real time PCR. Bars represent relative mRNA expression of TNF- $\alpha$ normalized to that of GAPDH. The data shown are the representative of three independent experiments with similar results. (C) PMA-differentiated THP-1 cells were treated with TCDD (75 nM) and EGFR activation was analyzed by immunoprecipiation of EGFR followed by an immunoblot analysis using an anti-phospho-EGFR antibody (Cat No. 4407, Cell Signaling Technology, Inc., Danvers, MA). (D) The experiment was carried out as in (B), except PP2 was co-treated with TCDD instead of PD153035. 


\section{ERK is involved in TCDD-induced up-regulation of TNF- $\alpha$ expression}

ERK is one of the major downstream effector molecules of EGFR and shown to be activated by AhR stimulation in Raw 264.7 mouse macrophage cells (Park et al., 2005). Therefore, we investigated whether ERK was activated in response to TCDD treatment and whether it was required for TCDDinduced TNF- $\alpha$ expression. ERK activation was assessed by an immunoblot analysis using phospho-ERK specific antibody. Upon TCDD treatment, ERK was activated within 30 min (Figure 5A, upper panel), and the activation was sustained for $6 \mathrm{~h}$. The ERK protein level was not changed by TCDD treatment (Figure 5A, lower panel). Increased ERK activation by TCDD was indeed mediated by EGFR, since inhibition of EGFR activity using a chemical inhibitor, PD153035 completely suppressed TCDD-induced ERK phosphorylation (Figure

A

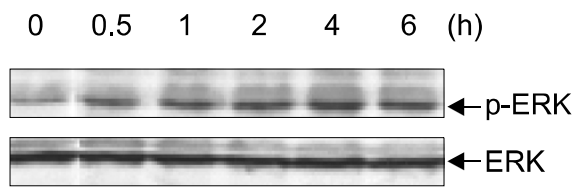

C

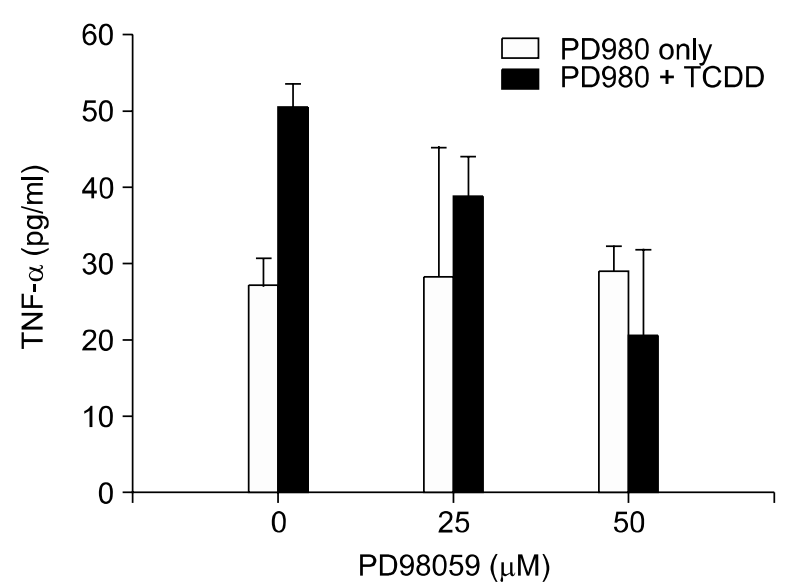

$5 B)$. The ERK activity was found to be required for the TCDD-induced TNF- $\alpha$ expression. PD98059, an inhibitor of the MEK-ERK pathway, prevented TCDD-induced expression of TNF- $\alpha$ mRNA and protein (Figure 5C and $\mathrm{D}$ ): The inhibition by PD98059 was dose-dependent with complete inhibition at $50 \mu \mathrm{M}$. However, other MAPK inhibitors such as a JNK inhibitor, SP600125, and a p38 MAPK inhibitor, SB203580, did not affect TCDDinduced TNF- $\alpha$ expression, and the evidence of p38 or JNK activation was not found in an immunoblot analysis (data not shown).

\section{Activation of EGFR and ERK by TCDD is AhR-dependent}

To investigate whether activation of the EGFR-ERK pathway following TCDD sitmulation depended on AhR, the effect of $\alpha$-NF on EGFR and ERK activation was assessed. Differentiated THP-1 cells were

B

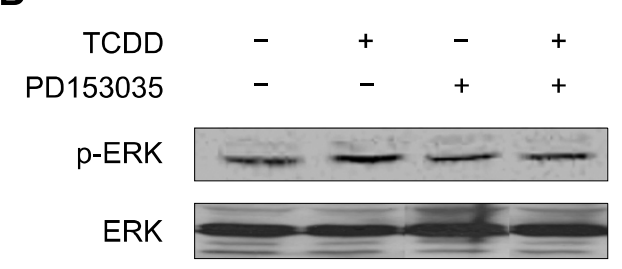

D

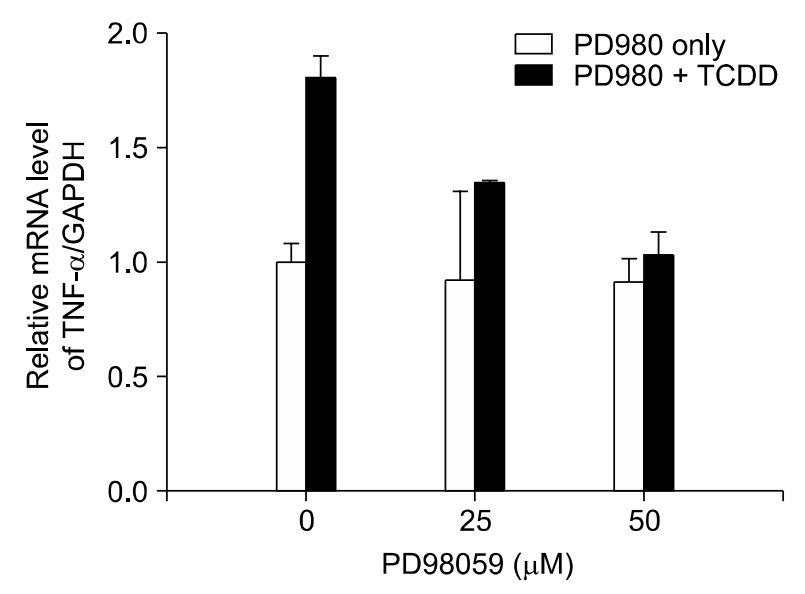

Figure 5. ERK activity is required for the TCDD-induced TNF- $\alpha$ expression. (A) After differentiation into macrophages with PMA, THP-1 cells were cultured in RPMI-1640 containing $0.5 \%$ FBS for $24 \mathrm{~h}$ before stimulation with TCDD $(75 \mathrm{nM})$. ERK activation was analyzed by an immunoblot analysis with anti-phospho-ERK antibody. The data are the representative of two independent experiments with similar results. (B) Differentiated THP-1 cells were co-treated with $50 \mu \mathrm{M}$ PD153035 and $75 \mathrm{nM}$ TCDD. After $1 \mathrm{~h}$. ERK activation was analyzed by an immunoblot analysis with an anti-phospho-ERK antibody. (C, D) PMA-differentiated THP-1 cells were pretreated with PD98059 for $2 \mathrm{~h}$, and stimulated with $75 \mathrm{nM}$ TCDD for $24 \mathrm{~h}$. The concentration of TNF- $\alpha$ in the culture supernatant was measured by L929 bioassay. The experiments were carried out in triplicate. Error bars represent standard deviation. The data shown are the representative of three independent experiments with similar results (C). The expression level of TNF- $\alpha$ mRNA was assessed by real time PCR. Bars represent relative mRNA expression of TNF- $\alpha$ normalized to that of GAPDH. The data are the representative of three independent experiments with similar results (D). 
A

$\begin{array}{rllll}\text { TCDD } & - & 5 & 10 & 5(\mathrm{~min}) \\ \alpha-N F & - & - & - & + \\ \text { p-EGFR } & \\ \text { EGFR }\end{array}$

B

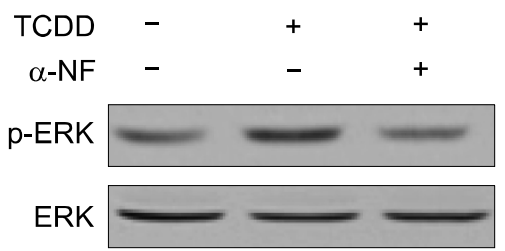

Figure 6. Activation of EGFR and ERK by TCDD is mediated by AhR. Differentiated THP-1 cells were treated with $75 \mathrm{nM}$ TCDD in the presence or absence of $1 \mu \mathrm{M} \alpha-\mathrm{NF}$. (A) At indicated time points, EGFR activation was analyzed by immunoprecipiation of EGFR followed by an immunoblot analysis of phospho-EGFR. (B) ERK activation was analyzed after $1 \mathrm{~h}$ by an immunoblot analysis with anti-phospho-ERK antibody.

co-treated with $\alpha-N F$ and TCDD, and after 5 min, EGFR was immunoprecipitated for an immunoblot analysis of EGFR phosphorylation. As shown in Figure $6 \mathrm{~A}, \alpha-\mathrm{NF}$ at $1 \mu \mathrm{M}$ completely blocked EGFR phosphorylation, suggesting that EGFR phosphorylation by TCDD requires AhR activation. Similarly, in accordance with the finding that EGFR mediated ERK activation after TCDD treatment, ERK activation by TCDD was significantly reduced by co-treatment of $\alpha-N F$. These results provide evidence that AhR mediates EGFR-ERK activation by TCDD.

\section{Discussion}

TNF- $\alpha$ was shown to be induced upon exposure to TCDD (Clark et al., 1991; Moos et al., 1997; Zeytun et al., 2002; Wu et al., 2004) and implicated in TCDD toxicity such as mortality, hypersensitivity to endotoxin, enhanced peritoneal inflammatory response, cachexia, and endometriosis (Clark et al., 1991; Moos et al,, 1994; Rier et al., 2001). However, most of the previous studies were based on a mouse model, and the detailed mechanism by which TCDD induces TNF- $\alpha$ production has not been clearly understood.

In the present study, it was shown that $\alpha-N F$, an AhR antagonist, completely prevented TNF- $\alpha$ expression mediated by TCDD, suggesting that AhR mediated it. This result is in contrast to benzo(a)pyrene-induced TNF- $\alpha$ secretion which was AhR- independent (Lecureur et al., 2005). In general, the ligand-activated AhR mediates the effect of TCDD by interacting with XRE in the 5'-flanking regions of target genes. However, AhR-regulated XREs have not been found in the 5'-flanking region of the human TNF- $\alpha$ gene (Sun et al., 2004). Therefore, it appears that other signaling pathway is involved rather than the ligand-activated AhR directly activates transcription of the TNF- $\alpha$ gene.

It has been reported that TCDD rapidly activates PKC and PTK in hepatocyte membranes (Bombick et al., 1985, 1988; Matsumura, 1994). The EGFR tyrosine kinase is known to be activated by TCDD and involved in TCDD-induced pathogenesis of liver and adipose tissues (Madhukar et al., 1988; Matsumura, 1994). In this study, it was found that EGFR was also involved in TCDD-induced TNF$\alpha$ expression in THP-1 macrophages. TCDD is not an EGFR ligand, and the TCDD-induced EGFR activation was mostly explained by an autocrine loop produced by a TCDD-induced expression and secretion of TGF- $\alpha$ and EGF (Gaido et al., 1992; Davis et al., 2003). Although the exact mechanism of EGFR activation in TCDD-induced TNF- $\alpha$ expression needs to be elucidated, our results show that EGFR activation occurs rapidly (within $5 \mathrm{~min}$ ) after TCDD stimulation and is mediated by AhR.

Functionally relevant EGFR activation should lead to an increase in ERK activation by phosphorylation. ERK phosphorylation in response to TCDD has been demonstrated in primary cultures of endocervical epithelium of macaque, and in Jurkat and mouse hepatoma cells (Enan et al., 1998b; Tan et al., 2002; Kwon et al., 2003). Our data showed that activation of ERK was required in TNF- $\alpha$ expression triggered by TCDD: Phosphorylation of ERK in differentiated THP-1 macrophages was induced within 30 min of TCDD treatment, and PD98059, an inhibitor of the MEK-ERK pathway, abolished TCDD-induced TNF- $\alpha$ expression. Increased ERK phophorylation by TCDD was abolished by an EGFR inhibitor, PD153035, indicating that TCDD-induced ERK activation is indeed mediated by EGFR. The RAS-RAF-MEK signaling pathway might mediate the ERK activation by EGFR tyrosine kinase (Puga et al., 2002). Alternatively, signaling molecules downstream of EGFR, such as PKC, PLC- $\gamma$ and PI3K, which are known to be involved in the induction of ERK activity by various stimuli, might be responsible for the TCDD-induced ERK activation (Puga et al., 2002). Although c-Src activation by TCDD has been reported (Madhukar et al., 1988), and ERK activation can be induced by $\mathrm{c}$-Src, it does not appear to be involved in TNF- $\alpha$ expression induced by TCDD. PP2, a specific inhibitor of the Src-family 
kinases, did not prevent TCDD-induced TNF- $\alpha$ expression (Figure 4C).

Although NF-KB is a well-known transcription factor activating TNF- $\alpha$ gene transcription, it does not seem to mediate the induction of TNF- $\alpha$ expression in TCDD-treated THP-1 macrophages. TCDD failed to increase DNA binding activity of NF-KB (data not shown). In this line, exposure of human macrophages to benzo(a)pyrene also induced TNF- $\alpha$ expression without enhancing NF- $\kappa B$ DNA binding activity (Lecureur et al., 2005). TCDD did not activate NF- $\mathrm{KB}$ in mouse models as well (Suh et al., 2002; Patterson et al., 2003), and even suppressed TNF- $\alpha$ - and anti-CD40-induced NF- $\mathrm{KB}$ activation in dendritic cells (Ruby et al., 2002). We also failed to observe the increased DNA binding activity of AP-1 by TCDD despite of ERK activation (data not shown).

In differentiated human THP-1 macrophages, TCDD increased both TNF- $\alpha$ mRNA expression and secretion of TNF- $\alpha$ protein in the absence of LPS. In contrast, in a murine macrophage cell line, Raw 264.7, TNF- $\alpha$ could only be induced by TCDD in the presence of LPS (Figure 1D). The requirement of LPS in TCDD-induced TNF- $\alpha$ secretion has also been shown in mouse peritoneal macrophages (Moos et al., 1997; Pestka and Zhou, 2006). Likewise, benzo(a)pyrene did not induce TNF- $\alpha$ secretion in Raw 264.7 cells, but benzo(a)pyrene plus carbon black caused release of TNF- $\alpha$ (Chin et al., 1998). The difference might be explained by a species-specific difference in the effect of TCDD on TNF- $\alpha$ induction. Another possibility is that the TNF- $\alpha$ production from macrophages requires pre-sensitization with LPS or other mitogenic signals before or along with the exposure to TCDD. In this case, PMA treated to differentiate the human promonocytic THP-1 cells prior to the TCDD exposure might have provided the necessary pre-sensitization as LPS might have done to mouse macrophages.

In summary, we found that TCDD enhanced TNF- $\alpha$ production in differentiated human THP-1 macrophages, and AhR, EGFR, and ERK participated in the TCDD-triggered signaling pathway leading to the increased TNF- $\alpha$ expression. Based on the evidence provided in this study, a signaling pathway for the TCDD-induced TNF- $\alpha$ expression is proposed that TCDD binds AhR which then activates the EGFR-ERK pathway through which expression of the TNF- $\alpha$ gene is up-regulated. Although the involvement of EGFR and ERK in TCDD-induced carcinogenesis was reported in many cases, it has not been known that they also play roles in TCDD-induced TNF- $\alpha$ expression. This pathway is distinct from that of LPS- or IL-1- induced TNF- $\alpha$ expression mediated by NF-kB. These results provide better understanding for the TCDD toxicity mediated by TNF- $\alpha$.

\section{Acknowledgement}

This research was supported by a grant of Medical Research Center for Environmental Toxicogenomic and Proteomics, funded by Korea Science and Engineering Foundations and Ministry of Science and Technology.

\section{References}

Ahmed S, Shibazaki M, Takeuchi T, Kikuchi H. Protein kinase Ctheta activity is involved in the 2,3,7,8-tetrachlorodibenzo-p-dioxin-induced signal transduction pathway leading to apoptosis in L-MAT, a human lymphoblastic T-cell line. FEBS J 2005;272:903-15

Alsharif NZ, Lawson T, Stohs SJ. Oxidative stress induced by 2,3,7,8-tetrachlorodibenzo-p-dioxin is mediated by the aryl hydrocarbon (Ah) receptor complex. Toxicol 1994;92: 39-51

Bombick D, Madhukar BV, Brewster DW, Matsumura F. TCDD (2,3,7,8-tetrachlorodibenzo-p-dioxin) causes an increase in protein kinases particularly protein kinase $\mathrm{C}$ in the hepatic plasma membrane of the rat and the guinea pig. Biochem Biophys Res Commun 1985;127:296-302

Bombick DW, Jankun J, Tullis K, Matsumura F. 2,3,7,8Tetrachlorodibenzo-p-dioxin causes increases in expression of c-erb-A and levels of protein-tyrosine kinases in selected tissues of responsive mouse strains. Proc Natl Acad Sci USA 1988;85:4128-32

Chin BY, Choi ME, Burdick MD, Strieter RM, Risby TH, Choi AM. Induction of apoptosis by particulate matter: role of TNF-alpha and MAPK. Am J Physiol 1998;275:L942-9

Clark GC, Taylor MJ, Tritxcher AM, Lucier GW. Tumor necrosis factor involvement in 2,3,7,8-tetrachlorodibenzop-dioxin-mediated endotoxin hypersensitivity in C57BL/6J mice congenic at the Ah locus. Toxicol Appl Pharmacol 1991;111:422-31

Davis JW, Burdick AD, Lauer FT, Burchiel SW. The aryl hydrocarbon receptor antagonist, 3'methoxy-4'nitroflavone, attenuates 2,3,7,8-tetrachlorodibenzo-p-dioxin-dependent regulation of growth factor signaling and apoptosis in the MCF-10A cell line. Toxicol Appl Pharmacol 2003;188:42-9

DeVito MJ, Birnbaum LS. Dioxins: model chemicals for assessing receptor-mediated toxicity. Toxicol 1995;102: 115-23

Dooley RK, Holsapple MP. Elucidation of cellular targets responsible for tetrachlorodibenzo-p-dioxin (TCDD)-induced suppression of antibody responses: The role of the $B$ lymphocyte. Immunopharmacol 1988;16:167-80

Enan E, Dunlap DY, Matsumura F. Use of c-Src and c-Fos knockout mice for the studies on the role of c-Src kinase signaling in the expression of toxicity of TCDD. J Biochem Mol 
Toxicol 1998a;12:263-74

Enan E, El-Sabeawy F, Scott M, Overstreet J, Lasley B. Alterations in the growth factor signal transduction pathways and modulators of the cell cycle in endocervical cells from macaques exposed to TCDD. Toxicol Appl Pharmacol 1998b;151:283-93

Gaido KW, Maness SC, Leonard LS, Greenlee WF. 2,3,7,8Tetrachlorodibenzo-p-dioxin-dependent regulation of transforming growth factors-alpha and -beta 2 expression in a human keratinocyte cell line involves both transcriptional and post-transcriptional control. J Biol Chem 1992;267:24591-5

Hossain A, Tsuchiya S, Minegishi M, Osada M, Ikawa S, Tezuka FA, Kaji M, Konno T, Watanabe M, Kikuchi H. The Ah Receprot is not involved in 2,3,7,8-tetrachlorodibenzop-dioxin-mediated apoptosis in human leukemic T cell lines. J Biol Chem 1998;273:19853-8

Kazlauskas A, Poellinger L, Pongratz I. Evidence that the co-chaperone $\mathrm{p} 23$ regulates ligand responsiveness of the dioxin (aryl hydrocarbon) receptor. J Biol Chem 1999;274: 13519-24

Kerkvliet NI, Baecher-Steppan L, Smith BB, Youngerberg JA, Henderson MC, Buhler DR. Role of the Ah locus in suppression of cytotoxic $\mathrm{T}$ lymphocyte activity by halogenated aromatic hydrocarbons (PCB and TCDD): structure-activity relationships and effects in C57B1/6 mice. Fundam Appl Toxicol 1990;14:532-41

Kwon MJ, Jeong KS, Choi EJ, Lee BH. 2,3,7,8-Tetrachlorodibenzo-p-dioxin (TCDD)-induced activation of mitogen-activated protein kinase signaling pathway in Jurkat $T$ cells. Pharmacol Toxicol 2003;93:186-90

Lecureur V, Ferrec EL, N'diaye M, Vee ML, Gardyn C, Gilot $D$, Fardel O. ERK-dependent induction of TNF $\alpha$ expression by the environmental contaminant benzo(a)pyrene in primary human macrophages. FEBS Lett 2005;579:1904-10

Luster MI, Germolec DR, Clark G, Weigand G, Rosenthal GJ. Selective effects of 2,3,7,8-tetrachlorodibenzo-p-dioxin and corticosteroid on in vitro lymphocyte maturation. $\mathrm{J}$ Immunol 1988;140:928-35

Ma Q, Whitlock JP. A novel cytoplasmic protein that interacts with the Ah receptor, contains tetratricopeptide repeat motifs, and augments the transcriptional response to 2,3,7,8tetrachlorodibenzo-p-dioxin. J Biol Chem 1997;272:887884

Madhukar BV, Ebner K, Matsumura F, Bombick DW, Brewster DW, Kawamoto T. 2,3,7,8-Tetrachlorodibenzop-dioxin causes an increase in protein kinases associated with epidermal growth factor receptor in the hepatic plasma membrane. J Biochem Toxicol 1988;3:261-77

Matsumura F. How important is the protein phosphorylation pathway in the toxic expression of dioxin-type chemicals? Biochem Pharmacol 1994;48:215-24

Moos AB, Baecher-Steppan L, Kerkvliet NI. Acute inflammatory responses to sheep red blood cells in mice treated with 2,3,7,8-tetrachlorobenzo-p-dioxin: the role of proinflammatory cytokines, IL-1 and TNF. Toxicol Appl Pharmacol 1994;127:331-5
Moos AB, Oughton JA, Kerkvliet NI. The effects of 2,3,7,8-tetrachlorodibenzo-p-dioxin (TCDD) on tumor necrosis factor (TNF) production by peritoneal cells. Toxicol Lett 1997;90:145-53

Park SJ, Yoon WK, Kim HJ, Son HY, Cho SW, Jeong KS, Kim $\mathrm{TH}$, Kim SH, Kim SR, Ryu SY. 2,3,7,8-Tetrachlorodibenzo-p-dioxin activates ERK and p38 mitogen-activated protein kinases in RAW 264.7 cells. Anticancer Res 2005; 25:2831-6

Patterson RM, Stachlewitz R, Germolec D. Induction of apoptosis by 2,3,7,8-tetrachlorodibenzo-p-dioxin following endotoxin exposure. Toxicol Appl Pharmacol 2003;190: 120-34

Pestka J, Zhou HR. Toll-like receptor priming sensitizes macrophages to proinflammatory cytokine gene induction by deoxynivalenol and other toxicants. Toxicol Sci 2006;92: 445-55

Puga A, Xia Y, Elferink C. Role of the aryl hydrocarbon receptor in cell cycle regulation. Chem Biol Interact 2002;141:117-30

Rier RE, Turner WE, Martin DC, Morris R, Lucier GW, Clark GC. Serum levels of TCDD and dioxin-like chemicals in Rhesus monkeys chronically exposed to dioxin: correlation of increased serum PCB levels with endometriosis. Toxicol Sci 2001;59:147-59

Ruby CE, Leid M, Kerkvliet I. 2,3,7,8-Tetrachlorodibenzop-dioxin suppresses tumor necrosis factor-alpha and anti-CD40-induced activation of NF-kappaB/Rel in dendritic cells: p50 homodimer activation is not affected. Mol Pharmacol 2002;62:722-8

Schmidt JV, Bradfield CA. Ah receptor signaling pathway. Annu Rev Cell Dev Biol 1996;12:55-89

Suh J, Jeon YJ, Kim HM, Kang JS, Kaminski NE, Yang KH. Aryl hydrocarbon receptor-dependent inhibition of AP-1 activity by 2,3,7,8-tetrachlorodibenzo-p-dioxin in activated $B$ cells. Toxicol Appl Pharmacol 2002;181:116-23

Sun YV, Boverhof DR, Burgoon LD, Fielden MR, Zacharewski TR. Comparative analysis of dioxin response elements in human, mouse and rat genomic sequences. Nucleic Acids Res 2004;32:4512-23

Tan Z, Chang X, Puga A, Xia Y. Activation of mitogenactivated protein kinases (MAPKs) by aromatic hydrocarbons: role in the regulation of aryl hydrocarbon receptor (AHR) function. Biochem Pharmacol 2002;64:771-80

Taylor MJ, Lucier GW, Mahler JF, Thompson M, Lockhart AC, Clark GC. Inhibition of acute TCDD toxicity by treatment with anti-tumor necrosis factor antibody or dexamethasone. Toxicol Appl Pharmacol 1992;117:126-32

Vassalli P. The pathophysiology of tumor necrosis factors. Annu Rev Immunol 1992;10:411-52

Whitelaw ML, Gottlicher M, Gustafsson J, Poellinger L. Definition of a novel ligand binding domain of a nuclear bHLH receptor: co-localization of ligand and hsp90 binding activities within the regulable inactivation domain of the dioxin receptor. EMBO J 1993;12:4169-79

Wu CH, Chen HL, Su LJ, Lee CC, Shen KT, Ho WL, Ho SY, 
Ho YS, Wang YJ. The topical application of 2,3,7,8tetrachlorodibenzo-p-dioxin lacks skin tumor-promoting potency but induces hepatic injury and tumor necrosis factor- $\alpha$ expression in ICR male mice. Food and Chem Toxicol 2004;42:1217-25
Zeytun A, McKAllip RJ, Fisher M, Camacho I, Nagarkatti M, Nagarkatti PS. Analysis of 2,3,7,8-tetrachlorodibenzop-dioxin-induced gene expression profile in vivo using pathway-specific cDNA arrays. Toxicol 2002;178:241-60 